\title{
Triterpenoid Constituents of Tissue Cultures and Regenerated Organs of Taraxacum officinale
}

\author{
Tetsuo Furuno, Aki Kamiyama, Tomoyoshi Akashi, Mariko Usui, \\ Takeyoshi TAKAHASHI and Shin-ichi AyABE* \\ Department of Applied Biological Science, College of Agriculture and Veterinary Medicine, \\ Nihon University, Fujisawa, Kanagawa, 252 Japan
}

(Received April 30, 1993)

(Accepted May 31, 1993)

\begin{abstract}
Complete plants were regenerated from callus cultures of Taraxacum officinale. Shoot cultures were first established on half strength Murashige-Skoog's medium containing $0.1 \mathrm{ppm} N^{6}$-benzyladenine with or without $0.1 \mathrm{ppm} \alpha$-naphthaleneacetic acid. These shoots regenerated roots on phytohormone-free medium, and then, upon transfer to soil in a pot, grew into complete plants with normal flowers and seeds. Triterpenoid constituents of the dedifferentiated callus cells, wild and regenerated shoot and root organs, and also of latex, were analyzed. Triterpene acids (oleanolic and ursolic acids) were found predominantly in callus cells. The composition of triterpen-3-ols was characteristically different between the organs: $\alpha$-and $\beta$-amyrins were found in all the tissues, whereas taraxasterol and lupeol were detected in differentiated organs.
\end{abstract}

\section{Introduction}

Taraxacum officinale (dandelion) roots have been reported to contain various types of pentacyclic triterpenoids (e.g. oleanane, ursane and taraxastane types : see Fig. 1$)^{1-3)}$. Among these, oleananeand ursane-derivatives are commonly found in the plant kingdom, while taraxastane-derivatives are distributed among narrower taxa ${ }^{4}$. Biosyntheses of these related but distinct skeletal types of triterpenoids could be attributed to the presence of different 2,3-oxidosqualene cyclases (OSCs) ${ }^{5}$, but the details of enzymatic mechanisms of triterpenoid biosyntheses and the regulating factors influencing the enzyme activities have hardly been investigated. On the other hand, in vitro organ regeneration of $T$. officinale has been reported $^{6-8)}$. Several volatile components of the suspension cultures have been detected, ${ }^{9)}$ but triterpenoids in cultured cells have not been explored so far. We describe here the complete plant regeneration from $T$. officinale callus cultures and the comparison of triterpenoid constituents of cultured cells and wild and redifferentiated tissues. The results are discussed from the viewpoint of triterpenoid biosynthesis/accumulation in relation to the morphological differentiation of the cells.

\section{Materials and Methods}

\section{Plant material and regeneration experiments}

T. officinale callus cultures, which had been derived from aseptic seedlings in the summer of 1990,

* To whom correspondence should be addressed. 

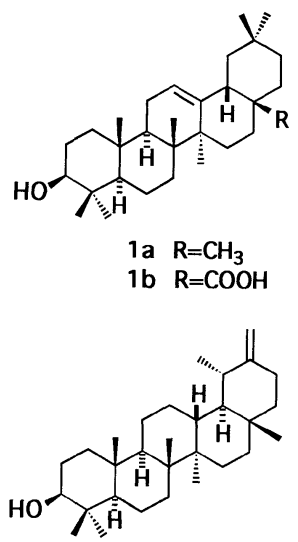

3

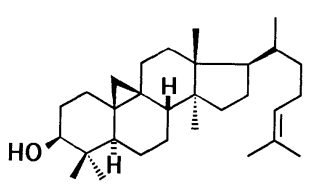

5
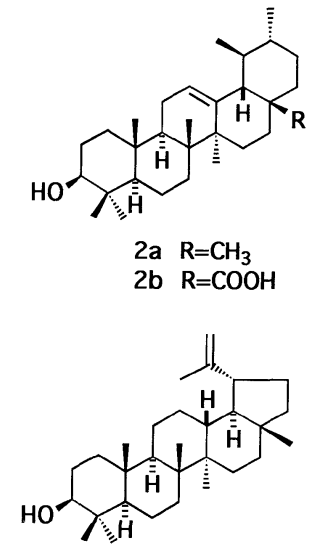

4

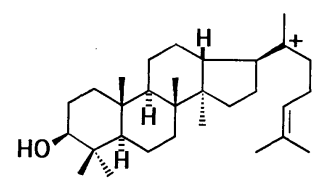

6

Fig. 1 Structures of triterpenoids from $T$. officinale.

were routinely maintained on Murashige-Skoog's (MS) ${ }^{10)}$ agar (0.9\%) medium supplemented with $1 \mathrm{ppm} 2$, 4-dichlorophenoxyacetic acid (2,4-D), $0.1 \mathrm{ppm}$ kinetin and $7 \%$ coconut water under the dark at $25^{\circ} \mathrm{C}$ with 3 -week culture cycle. The dark-grown cells (after ca. one and a half year of subculture) were transferred onto the media described in Results and incubated under $12 \mathrm{~h}$ light (3,000-5, 000 lux)/12h dark cycle to achieve organ differentiation.

\section{Triterpenoid analysis}

Roots and leaves of wild plants were air-dried, and redifferentiated organs were lyophilized before extraction. These materials were extracted with hot $\mathrm{CCl}_{4}(15-20 \mathrm{ml} / \mathrm{g}$ tissue), and the constituents were initially determined by silica-gel TLC (Kiesel gel $60 \mathrm{~F}_{254}$; solvent, toluene/ EtOAc $=4 / 1)$ together with standard samples $(\beta$ - and $\alpha$-amyrins, $1 \mathbf{a}$ and $\mathbf{2} \mathbf{a}$; oleanolic and ursolic acids, $\mathbf{1} \mathbf{b}$ and $\mathbf{2}$ b, Rf ca. 0.12 ; cycloartenol, 5). Triterpen-3-ols (Rf $c a .0 .38$ ) were then separated by preparative TLC, dissolved in appropriate volumes of $\mathrm{CHCl}_{3} / \mathrm{CH}_{3} \mathrm{CN}(3 / 2)$, and, aliquots were applied to HPLC (column, Shimpack CLC-ODS, $0.15 \mathrm{~m} \times 6 \mathrm{~mm}$, Shimadzu; eluent, $90 \%$ aq. $\mathrm{CH}_{3} \mathrm{CN}$; flow rate, $2 \mathrm{ml} / \mathrm{min}$. ; detection, UV $205 \mathrm{~nm}$ ). Latex was collected from the cuttings of the original plants, and, after the addition of water, extracted with EtOAc. The concentrated EtOAc layer was analyzed as above.

\section{Results}

\section{Plant regeneration from cultured cells}

T. officinale callus cultures on MS medium containing 2, 4-D and kinetin under the dark exhibited a heterogeneous mixture of colorless fragile cells and gray-colored hard cells. In a preliminary experiment, the cells were transferred onto MS media with various concentrations ( 0 to $2.5 \mathrm{ppm}$ ) of $\alpha$-naphthaleneacetic acid (NAA) and/or $N^{6}$-benzyladenine (BA). Under illumination, those subcultured on media containing $0.05 \mathrm{ppm} \mathrm{NAA}$ with or without $0.05 \mathrm{ppm}$ BA formed adventitious shoots in 4 weeks, and then spontaneously formed roots after 2 months. Higher concentrations of 
A
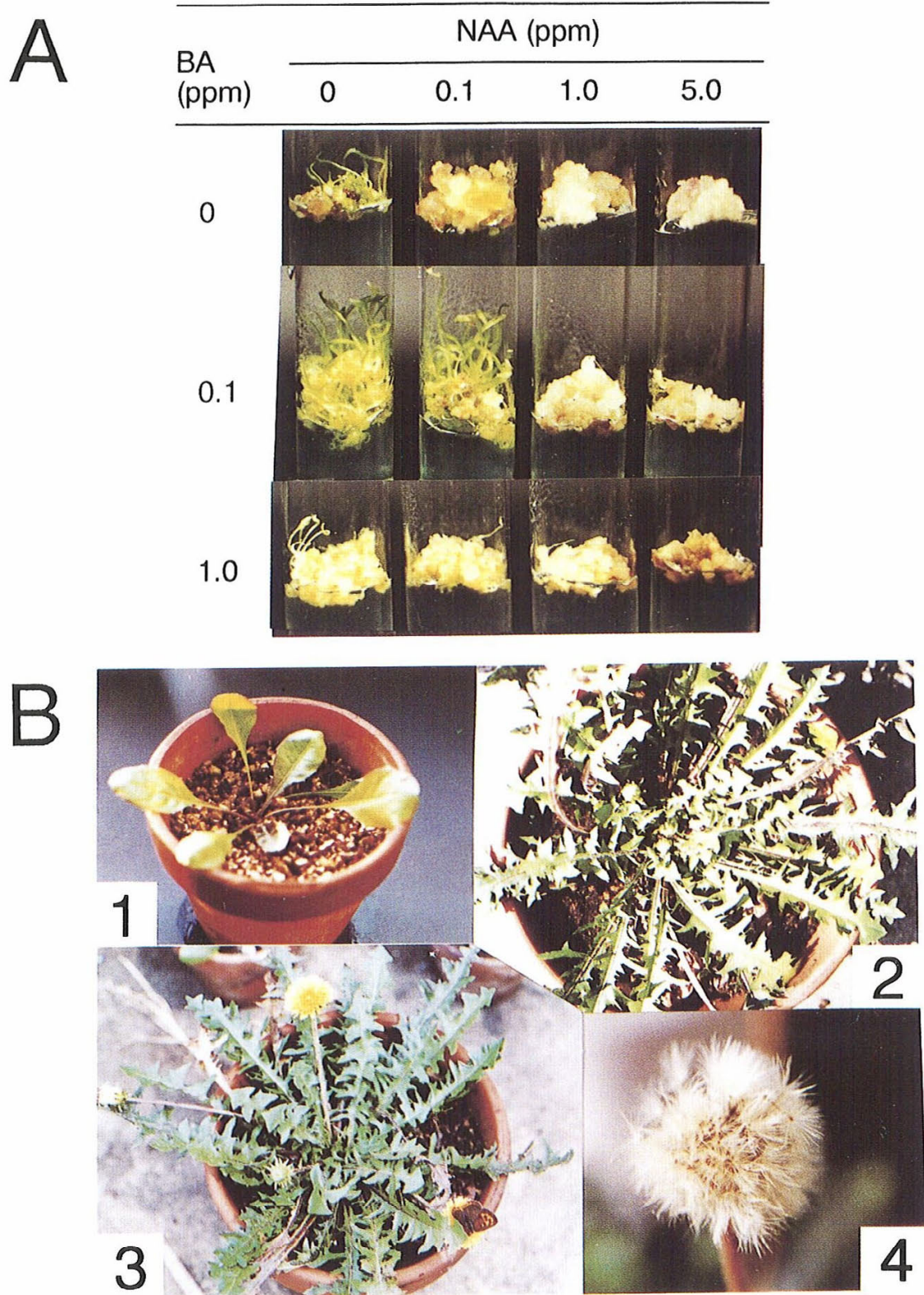

Fig. 2 Plant regeneration from $T$. officinale callus cells.

A : Effects of NAA and BA on organ differentiation.

Dark-grown callus cells were transferred onto $1 / 2 \mathrm{MS}$ media containing the indicated concentrations of NAA and BA, and incubated at $25^{\circ} \mathrm{C}$ under $12 \mathrm{~h}$ light $/ 12 \mathrm{~h}$ dark cycle with 3 -week culture cycle. The photographs show 3 -week-old tissue cultures of the third passages of subculture.

B : Plant regeneration from in vitro shoot cultures.

The shoots on the medium with $0.1 \mathrm{ppm} \mathrm{BA}$ in $\mathbf{A}$ were cultured on hormone-free medium to form roots, and further transferred to vermiculite (1). After 2 months, the plantlet grew to a mature plant (2), formed flowers (3), and then seeds (4). 
BA ( 0.5 or $2.5 \mathrm{ppm})$ were also effective for shoot formation when NAA levels were low $(0$ or 0.05 $\mathrm{ppm}$ ). However, mature plants could not be regenerated when the plantlets were transferred out of the culture vessels to the soil in pots. In the dark, most of the cells on media with various hormone concentrations showed undifferentiated growth, and no clear root or shoot formation was observed.

Half strength Murashige-Skoog's basal media (1/2 MS; solidified with $0.2 \%$ gellan gum) containing either or both of NAA and BA $(0.1,1.0$, and $5.0 \mathrm{ppm}$ each) were then employed for plant regeneration (Fig. 2-A). Adventitious shoot formation was frequently observed among the cells on BA-containing ( 0.1 or $1.0 \mathrm{ppm}$ ) and hormone-free media. After 3 to 4 passages of transfer, shoot cultures were established on media with only $0.1 \mathrm{ppm} \mathrm{BA}$ and with both $0.1 \mathrm{ppm}$ BA and NAA. Those shoots were transferred onto the phytohormone-free medium (root regeneration medium). Otherwise, shoots were dipped in water for 2-3 days to form roots. Plantlets thus formed were transferred to vermiculite in a pot and then to the soil. In about 2 months (June to August) many mature leaves grew, and some plants produced normal flowers (Fig. 2-B). Even fertile seeds could be recovered. Starting from the dark-grown callus, $c a$. half a year was needed to obtain seeds.

\section{Triterpenoid components of $\mathrm{T}$. officinale original plant, cultured cells and regenerated organs}

Triterpenoid constituents of morphologically different cells (wild plants, callus, and regeneated organs) were analyzed. TLC analysis of the $\mathrm{CCl}_{4}$ extract of the callus cells (ca.3-week-old) showed a very conspicuous spot of triterpene acids, but only small amounts of triterpen-3-ols with 4, 4-dimethyl substituents. In contrast, the extracts of the original plant organs, especially that of the roots, showed a prominent spot at the position of triterpen-3-ols. Triterpene acids were scarcely detected in those wild plant extracts. In the young shoots (as in Fig. 2-A) as well as the thin roots regenerated from callus cultures, triterpen-3-ols and triterpene acids co-occurred. When the regenerated plants were mature, as expected, the TLC patterns were indistinguishable from that of wild plant organs.

Triterpene acids were isolated from a large scale suspension-culture of undifferentiated cells, and crystallized and identified as a mixture of oleanolic acid (1b) and ursolic acid (2b) by EI-mass, ${ }^{1} \mathrm{H}-$ and ${ }^{13} \mathrm{C}-\mathrm{NMR}$ spectra (data not shown). The content of triterpene acids was $c a .0 .3-0.5 \mathrm{mg} / \mathrm{g}$ dry wt. in callus cultures. Reversed-phase HPLC analysis (see below) of triterpene acids was hampered by peak-broadening and poor resolution of the components, but showed virtually no detectable amount of acids in wild plant organs (data not shown). About $0.5 \mathrm{mg} / \mathrm{g}$ dry wt. of triterpen-3-ols could be detected in callus cultures, while $2-8 \mathrm{mg} / \mathrm{g}$ dry wt. were contained in shoots and roots of intact plants.

Silica-gel TLC with EtOAc/toluene as a developing solvent cannot distinguish individual triterpen-3-ols, but reversed-phase HPLC with $\mathrm{CH}_{3} \mathrm{CN} / \mathrm{H}_{2} \mathrm{O}$ as an eluent successfully differentiates them. As shown in Fig. 3, a total of five triterpen-3-ols could be separated from the eluates of various $T$. officinale tissue and cell extracts. The identity of each compound was confirmed by the retention time of a corresponding standard sample and/or EI-mass/NMR $\left({ }^{1} \mathrm{H}-\right.$ and $\left.{ }^{13} \mathrm{C}-\right)$ data of the specimen prepared from repeated collection of the eluate ${ }^{11,12}$. In callus cells major triterpen-3 -ols were $\beta$ - and $\alpha$-amyrins (1a and $\mathbf{2 a}$, respectively). In comparison, wild plants and regenerated organs additionally contained different skeletal types of triterpenoids. These were found to be taraxasterol (3) and lupeol (4); the ${ }^{13} \mathrm{C}-\mathrm{NMR}$ data of those were the most diagnostic for the structural identification ${ }^{12)}$. Cycloartenol (an intermediate triterpen-3-ol of phytosterol biosynthesis, 5) could also be detected in differentiated organs. In addition, clearly seen from Fig. 3, latex displayed an increased ratio of taraxasterol content among triterpen-3-ols compared to that of 


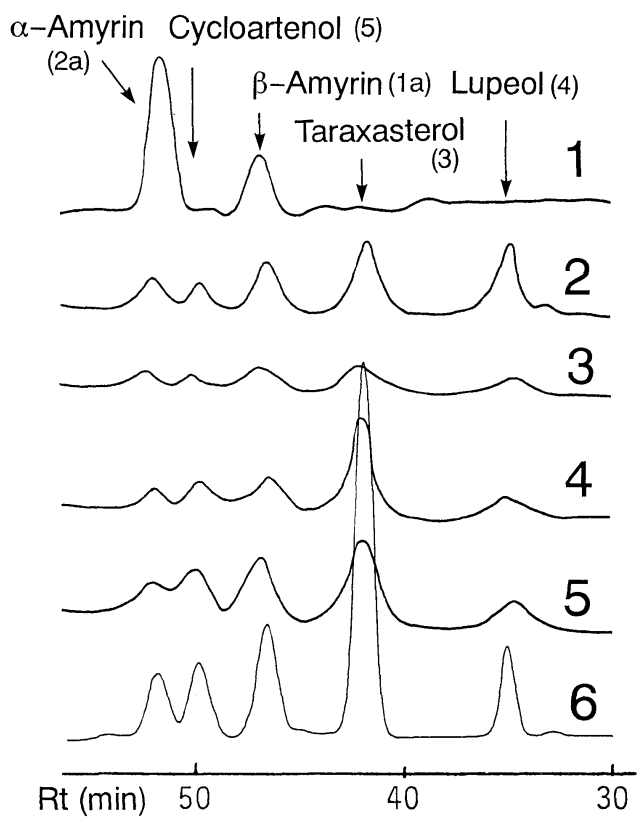

Fig. 3 Reversed-phase HPLC chromatograms of triterpen-3-ols in $\mathrm{CCl}_{4}$ extracts of callus, differentiated organs and intact plant organs, and in an EtOAc extract of latex, of $T$. officinale.

Triterpenoid fractions extracted from the same amount of dried materials $(0.5 \mathrm{~g})$ were applied on the column (except for lane 6). For HPLC conditions, see Materials and Methods. Lanes : 1 , callus (dark) ; 2 , original shoot ; 3 , regenerated shoot ; 4 , original root; 5 , regenerated root; 6 , latex.

other cells and organs.

\section{Discussion}

In the present study, cultured cells as well as intact and regenerated organs of $T$. officinale were demonstrated to possess the ability to cyclize 2,3-oxidosqualene into triterpen-3-ols with different backbone skeletons. Characteristically, accumulation of $\beta$-and $\alpha$-amyrins (1a and 2a) was observed in all types of the cells, while production of other types of compounds [taraxasterol (3) and lupeol (4) ] appeared to be accompanied by shoot and root regeneration. Likewise, in the tissue cultures of Glycyrrhiza glabra var. glandulifera, $\beta$-amyrin biosynthesis from $\left[2-{ }^{14} \mathrm{C}\right]$ mevalonic acid has been correlated with root differentiation ${ }^{13)}$. A recent report ${ }^{14)}$ indicates that bryonolic acid (friedooleanane type triterpene) biosynthesis takes place mainly. in radicles and callus cells of cucurbitaceous plants. Such a correlation of morphological differentiation and biosynthesis/accumulation of secondary metabolites is often encountered in production of phytochemicals by plant cells, and is usually interpreted as the result of organ-specific expression of biosynthetic genes.

Several OSC activities in plant cells yielding different products have recently been demonstrated to be relevant to the regulation of triterpenoid biosynthesis ${ }^{15-17)}$, but only cycloartenol cyclase and $\beta$-amyrin cyclase have been purified from single sources (pea seedling $\mathrm{s}^{18,19)}$ and cultured Rabdosia japonica cells ${ }^{5)}$ as distinct proteins, i.e. the products of different genes. Interestingly, all the pentacyclic triterpen-3-ols (1-4) detected here are biosynthetically derived from a single dammarane-type cation (6), via E-ring closure, ring expansion, and methyl- and hydride-shifts ; in contrast, cycloartenol (5) is derived from a distinct protostane-type cation ${ }^{4)}$. Hence there should be at least two 
OSCs in $T$. officinale, but no further information about the numbers or organization of the enzymes is available. In the future studies, it must be examined whether the organogenesis-related Taraxacum triterpenoid biosynthesis is the result of the organ-specific expression of genes encoding different OSCs or that other factors influence the biosynthesis/accumulation patterns.

Also, $\beta$ - and $\alpha$-amyrins (1a and $\mathbf{2 a}$ ) were shown to be further oxidized to triterpene acids (1) and 2b) particularly in undifferentiated cells, implying that as the cells differentiate into organs the putative enzyme activities involved in the oxidation of the triterpen-3-ols to triterpene acids become low.

Of particular interest may be that $T$. officinale is a latex-producing plant. We expect to clarify if differentiation of laticifer cells have any connection with specific triterpene (e.g. taraxasterol) formation, as in the case of morphinan alkaloid biosynthesis in Papaver cells ${ }^{20)}$. Biosynthetic ability of triterpenes and their esters in the latex of Euphorbia spp. has been discussed ${ }^{21}$.

In conclusion, our system is an attractive material for the examination of OSC activities in relation to organogenesis, and we are currently examining the triterpenoid biosynthetic ability of different cell types by in vivo labeling experiments and by in vitro enzyme assays.

\section{References}

1) Power, F. B., H. Browing, 1912. J. Chem. Soc., $101: 2411-2429$.

2) Burrows, S., J. C. E. Simpson, 1938. J. Chem. Soc., 2042-2047.

3) Ames, T. R., J. L Beton, A. Bowers, T. G. Halsall, E. R. H. Jones, 1954. J. Chem. Soc. 1905-1919.

4) Dev, S., A. S. Gupta, S. A. Patwardhan, 1989. "CRC Handbook of Terpenoids. Triterpenoids" (ed. by Dev, S.), Volume II, CRC Press, Boca Raton.

5) Abe, I., Y. Ebizuka, S. Seo, U. Sankawa, 1989. FEBS Lett., 249 : 100-104.

6) Bowes, B. G., 1970. Protoplasma, $71:$ 197-202.

7) Booth, A., R. Satchuthananthavale, 1974. New Phytol., $73: 445-452$.

8) Booth, A., R. Satchuthananthavale, 1974. New Phytol., $73: 453-460$.

9) Hook, I., H. Sheridan, G. Wilson, 1991. Phytochemistry, 30 : 3977-3979.

10) Murashige, T., F. Skoog, 1962. Physiol. Plant., $15: 473-497$.

11) Talapatra, S. K., M. Bhattacharya, B. Talapatra, 1973. Indian J. Chem. Soc., 11 : 977-980.

12) Patra, A., A. K. Mukhokadhyay, A. K. Mitra, 1981. Org. Magn. Reson., 17 : 166-168.

13) Ayabe, S., H. Takano, T. Fujita, T. Furuya, H. Hirota, T. Takahashi, 1990. Plant Cell Rep., 9 : 181-184.

14) Cho, H. J., S. Tanaka, H. Fukui, M. Tabata, 1992. Phytochemistry, 31 : 3893-3896.

15) Henry, M., A. Rahier, M. Taton, 1992. Phytochemistry, 31:3855-3859.

16) Taton, M., P. Benveniste, A. Rahier, W. S. Johnson, H. Liu, A. R. Sudhakar, 1992. Biochemistry, 31 : $7892-$ 7898.

17) Shimakura, J., H. J. Cho, S. Tanaka, H. Fukui, W. Kamisako, M. Tabata, 1993. Plant Cell Rep., 12 : 264267.

18) Abe, I., Y. Ebizuka, U. Sankawa, 1988. Chem. Pharm. Bull., $36: 5031-5034$.

19) Abe, I., U. Sankawa, Y. Ebizuka, 1989. Chem. Pharm. Bull., 37 : 536-538.

20) Kutchan, T. M., S. Ayabe, C. J. Coscia. 1985. In "The Chemistry and Biology of Isoquinoline Alkaloids" (eds. by Phillipson, J. D., M. F. Roberts, M. H. Zenk), p. 282-294, Springer-Verlag, Berlin.

21) Nemethy, E. K., C. Skrukrud, G. J. Piazza, M. Calvin, 1983. Biochim. Biophys. Acta, 760 : 343-349. 


\section{《和文要約》}

西洋タンポポ(Taraxacum officinale) 組織培養と再生器官の

トリテルペノイド成分

古野哲郎・神山西紀・明石智義・臼井真理子・高橋武美・綾部真一

\section{日本大学農獣医学部応用生物科学科}

西洋タンポポのカルス培養細胞から完全な植物体を再生させた。カルス細胞を NAA と BA を添加した $1 / 2 \mathrm{MS}$ 培地上明所で培養すると，一部の培地上で著しいシュートの形成が見られた，ホルモン無添加培地 で発根させ，バーミキュライトを経てポット中の土壤に移植したところ，開花し，種子を得る事ができた。 カルス培養ではトリテルペン酸(オレアノール酸, ウルソール酸)が顕著に検出されたが, 再分化すると検出 されなくなり, 代わりに分化器官ではトリテルペン-3-オール量が増加した。 トリテルペン-3-オールの組成 をHPLCで解析したところ, カルスでは $\alpha$-および $\beta$-アミリンが主要な成分であるのに対して, 分化器官 では夕ラキサステロール，ルペオールなどがさらに見出され，特に乳液では夕ラキサステロールが主成分で あった。 